\title{
Analysis of Financial Intermediation and Profitability: "A Case Study of the Ghanaian Banking Industry"
}

\author{
Richard K. Akoto ${ }^{1} \&$ Gladys A. A. Nabieu ${ }^{1}$ \\ ${ }^{1}$ Department of Banking \& Finance, University of Professional Studies, Accra (UPSA), Ghana \\ Correspondence: Gladys A. A. Nabieu, Department of Banking \& Finance, University of Professional Studies, \\ Accra (UPSA), Ghana. E-mail: gladys.nabieu@upsamail.edu.gh
}

Received: February 18, 2014

Accepted: March 8, 2014

Online Published: April 25, 2014

doi:10.5539/ijef.v6n5p220

URL: http://dx.doi.org/10.5539/ijef.v6n5p220

\begin{abstract}
The study examines the extent to which banks in Ghana have performed their financial intermediation function and its implication for profitability. Secondary data which was solicited from the Headquarters of the eight largest banks in Ghana was obtained from their financial reports from 2004 to 2010. Using descriptive examination technique, it is observed that all the banks performed creditably well within the period under study though the private banks performed better than the state-owned banks. Additionally, on the average, banks that mobilized the most deposits were also the ones that recorded most loans and advances. Interestingly, the study finds however that banks that made the most loans and advances were not necessarily those that made most profits. It is recommended that to remain profitable in the banking business in Ghana, management must not only put strategies in place to mobilize deposits and make out loans and advances but also institute procedures to efficiently manage cost. Furthermore, government must also put policies in place to motivate banks mobilize more deposits and make out more loans to deepen the financial system.
\end{abstract}

Keywords: banks, deposits, loans and advances, profitability, economic growth, cost management

\section{Introduction}

Financial intermediation basically involves deposit mobilisation from the surplus units of an economy and channelling those funds as loans and advances to the deficit units of the economy thus, allowing for efficient allocation of financial resources in the financial system. For the banking sector to remain profitable, Obamuyi (2013) argues that banks must efficiently mobilise more deposits to enable them grant more loans and advances. This means that there exist an association between deposits mobilisation and bank lending. Furthermore, Vohra and Sehgal (2012) posit that the ability of banks to perform this function efficiently has implications for their profitability. The finance literature additionally provides another strand of argument in support of the view that countries with efficient financial systems grow faster, while inefficient financial systems stand the perils of bank failures and lags behind in economic growth and development (Shaw, 1973; Kasekende, 2008; Northcoth, 2004). The authors further observe that the efficiency of a financial system is determined by the cost and speed with which deposits are mobilised and credit facilities extended to customers.

From the beginning of 1980s, governments of most developing economies started implementing major reforms aimed at revitalising their financial systems in order to achieve economic development. Empirical studies conducted several years later to assess the efficacy of these reforms appear to have shown mixed results. For example, Obamuyi (2013) relates that the financial system of most developing countries still remain largely under developed and thus needed to be revitalised to stimulate the needed economic growth and development. Additionally, Mohammed (2006) observed that the financial systems in most developing countries are vastly fragmented, inefficient, and uncompetitive. Alternatively, similar studies conducted in developed economies generally demonstrated that indeed increased and efficient financial intermediation leads to bank profitability, stability and economic development.

To deepen the financial system in Ghana, several financial and economic reforms were implemented since 1983. For example, the famous FINSAP 1 \& II under the Economic Recovery Programme was implemented in Ghana in the 1980s to revitalise the financial system to motivate economic growth and development. Intriguingly, several years after the implementation of these reforms in Ghana, formal evidence-base studies that specifically examine the association among deposit mobilisation, lending activity, and bank profitability are rare. This study 
therefore attempts to fill this gap by using a descriptive methodology technique to investigate these relationships. Broadly, the study aims at investigating the extent to which banks have performed their financial intermediation function in Ghana. Specifically, the study will first examine the effectiveness and extent to which banks have mobilised deposits and grant-out loans and advances to their customers and secondly, to assess whether there are any relationship between these and profitability of the banks.

To achieve the objectives of the study, the following questions are posed: Firstly, what is the extent and efficiency of deposit mobilisation of banks in Ghana? Secondly, is there any trend in the deposit mobilisation and granting of loans and advances of banks in Ghana? Thirdly, is there any trend between the deposit mobilisation, lending activity and bank profitability in Ghana? The relevance of this study is threefold. First, it may enhance decision making at bank managerial level on issues about efficiency in financial intermediation and profitability which are critical issues in ensuring financial system stability, and economic growth and development; Second, the findings may guide government in formulating policies on financial intermediation aimed at enhancing bank financial intermediation function; and finally, the findings of this study may have pedagogical importance to academics who are endlessly finding new trends in corporate activity. The paper is divided into five sections: The next section discusses banking in Ghana. Section two considers the related literature. Section three discusses the research methodology used. Section four deals with results and discussions and the final section discuss the conclusions and recommendations of the study.

\subsection{Banking in Ghana}

The Ghanaian banking system consists of licensed financial institutions basically dealing in the business of banking under the banking laws of Ghana. Bank of Ghana is the central bank that governs the activities of all the financial institutions. The banking sector over the last decade has recorded significant growth and improvements in performance as a result of the Financial Sector Adjustment Programme (FINSAP I \& II), Non-Performing Assets Recovery Trust (NPART) and the Foreign Exchange Bureau legislation (FEBL) reforms instituted by governments before this period. In 1989, a new Banking Law was passed and the Bank of Ghana was strengthened to enhance its capacity to play its regulatory role. These reforms and the new banking law has since strengthened the banks in terms of their capital base, managerial competence, and enhanced the supervisory proficiency of Bank of Ghana. Besides, the reforms has facilitate the improvement of the quality of assets being held by banks; built up investors confidence in the financial system and above all increased the profitability of the banks.

From 1957 to 1983, there were only twelve banks comprising of four (4) private banks and eight (8) public banks. Over the last decade and beyond, eleven (11) new banks were incorporated to do banking business in Ghana. These banks were all private except the Trust Bank (TTB) that had its major shareholder being the Social Security and National Insurance Trust (SSNIT). During this periods till date, some significant events such as the mergers (SSB and National Savings and Credit Bank), liquidation of Bank for Housing and Construction (BHC, Co-operation Banks), and privatization of state owned banks (GCB, SSB, NIB) has taken place.

The banking sector in Ghana has conventionally been segmented into commercial (retail), merchant, and developmental banks. While merchant banks have been restricted to corporate clients, the commercial and development banks have traditionally had customers across the entire financial market segments. However, since 2003, the Bank of Ghana formulated a policy issue to replace the three-pillar banking model-commercial, merchant and developmental banking with universal banking in order to provide all banks the opportunity to expand their activities, and opened up the financial system to competition, product innovation and the freedom to engage in permissible banking business without restrictions and boundaries. With improved macroeconomic conditions and prospects, the industry has grown into twenty six (26) commercial banks, diversified in geographical origin, corporate character and reach in the global financial markets. In the last decade, competition in the Ghanaian banking sector has soared over the period, with commercial and developmental banks trading beyond their perceived traditional functions and venturing into international trade financing, commerce and corporate lending, treasury services, payment financing, syndication, etc., which should have been the preserve line of business for merchant banks.

One area that has seen fierce competition in the banking industry is the area of product development. New products such as international funds transfer, school fees loan, negotiable certificate of deposit, car loans, consumer or hire purchase loans, travellers' cheques, minor savings accounts, insurance policy packages, etc. have been developed. Another improvement that has occurred over the last decade is automation and networking of branches. Almost all the banks have nationwide branch networking and this technological advancement has vastly improved banks operations and swift information processing. 
Automated teller machines (ATMs) have become common giving clients the freedom to transact business at their own convenience, thus reducing bank cost of attending to many customers in the banking halls. Also electronic banking, such as telephone banking, internet banking, Short Message Service (SMS) banking etc. has been introduced. The banks have pursued consistent programmes of sponsorship, promotion, advertisement of their services and products in the published and electronic media. The Ghanaian banking sector landscape can be said to be evolving, monopolistically competitive Biekpe (2011) and promising in terms of savings mobilization, development financing and service delivery.

\section{Literature Review}

The theoretical underpinning of this paper is rooted in the seminal work of Shaw (1973) who argues that the financial systems in developing economies are flawed with low level of formal intermediation. Following this pioneering paper, several empirical works have been carried out to investigate his position after most developing countries have taken conscious steps to liberalise their financial systems.

Basically, a true liberalised financial system is the one in which enough deposits are efficiently mobilised and sufficient loans and advances granted to credit worthy customers couple with the "independence" of the financial system from government interference. Generally, loans or "credit" constitutes the largest single income-earning asset in the portfolio of most banks. According to (Carletti, 2004), this explains why banks spend substantial resources to estimate, monitor and manage credit quality. Nonetheless, it is important for us to observe that a bank's lending capacity and financial success is largely dependent on its ability to mobilise enough deposits. Shaw (1973) and McKinnon (1973) find that this financial intermediation activity has implication for economic development of nation. Besides, we must however recognise that several factors influence this intermediation process thereby preventing the financial system from operating at its optimal level.

While investigating factors that affect lending rates, degree of lending volume and collateral setting in the loan decision making of Thai banks, Suwanaporn (2004) observes that Thai banks' lending decisions have sufficient systematic structures in place, which is not chaotic as speculated by many. Additionally, Thai banks partly consider borrower's risk in their lending decision, especially the degree of lending volume but do not make use of these risk indicators in the pricing of the loans. The author thus stressed that Thai banks need to be more careful with their lo an pricing decisions so as to prevent bad loans. This implies that 'loan mispricing' emanating from not fully incorporating the risk associated with lending volumes into lending rates and other customer risk factors may have negative consequences for the financial intermediation process, bank profitability, financial system instability and economic decay.

In a recent study, Obamuyi (2013) reaffirms that banks with high deposits and loans perform better in terms of profitability than banks with low deposits and loans. The author suggested that, since high deposits and loans enhance profitability, policy makers must make savings attractive in order to positively influence the liquidity position of the banks and their lending behaviour. The author further argues that, Nigerian commercial banks observed an era of remarkable profitability, characterized by high competition, huge deposits and varied investment opportunities. This development in the banking industry suggests that banks with well efficient deposits mobilization drive with high-quality lending behaviour will be the most profitable.

In a similar study, Haron and Azmi (2006) investigated the structural determinants of deposits level of commercial banks in Malaysia using co-integration technique. The study discover that the major determinants of deposit levels of Malaysian Commercial banks include: deposit rate of interest, base lending rate, Kuala Lumpur Composite Index, Money supply and Gross Domestic Product. The authors further establish that in most cases, bank customers behave in conformity with the saving behaviour theory which has implications for lending activity and profitability.

In addition, Okoye and Onyekachi (2013) examine the effects of lending rate and monetary policy rate on the financial performance of Banks in Nigeria. They observed that, lending rate and monetary policy rate both had a significant and positive effect on the financial performance of Nigerian deposit money banks. The authors relate that since lending is irrefutably the engine of the banking business, its administration which requires sufficient deposit mobilisation and cost reduction strategies must rigorously be pursued to achieve profitability, financial stability and economic development. The findings suggest that deposit mobilisation is at the heart of banks' lending activity and financial success among other things.

In a study of the link between monetary policy and banks lending behaviour in Ghana, Amidu (2006) observed that, Ghanaian banks' lending behaviour is affected significantly by the country's economic activities and changes in money supply. The results of his study also support previous studies that the central bank's prime rate and inflation negatively but insignificantly affect banks lending. With the firm level characteristics, the study 
reveals that bank size and liquidity significantly influence banks' ability to extend credit. Since deposits and its effective management are critical for resilient liquidity position of banks, it presupposes that sufficient deposit levels and prudent lending behaviour are keys for banks' profitability with its associated consequences for financial stability and economic development.

According to Vohra and Sehgal (2012) sufficient deposit mobilization and careful lending behavior are the two most important functions of banks since their profitability and survival depend on these. The authors noted that interest income constitutes the single most important part of banks profit. It is therefore clear that high deposit levels and prudent credit behavior are critical factors for bank profitability, financial system stability and economic development.

Finally, since the profitability and survival of businesses depend largely on availability of funds, and deposits constitute the major source of bank financing, it is apparent that there exist a relationship among efficient deposit mobilization, bank lending behavior, and profitability (Bologna, 2011). This explains why most banking firms have put in place aggressive deposit mobilization strategies with focus on customer need identification and offering of sophisticated banking products.

\section{Research Methodology}

The primary purpose of this paper is to examine the efficiency with which banks in Ghana mobilizes deposits and advances loans to their customers with the view of making profit. In his seminal work, Shaw (1973) argued that for the financial system to function smoothly, banks have a primary responsibility to efficiently mobilize funds from the surplus unit of the economy and reallocate it to the deficit unit of the economy. Secondary data which spanned from 2004 to 2010 was obtained from the annual reports of the eight largest Ghanaian banks in terms of total assets and was solicited from the headquarters of the selected banks. These banks include: Ghana Commercial Bank (GCB), Standard Chartered Bank (SCB), Barclays Bank Ghana Ltd. (BBGL), Ecobank Ghana (EBG), Agricultural Development Bank (ADB), Stanbic Bank (STANBIC), Merchant Bank Ghana (MBG), and National Investment Bank (NIB). According to the Ghana Banking Survey (2012), over 70\% of the Ghanaian bankable population is served by these banks hence their relative importance in terms of total assets and country presence. The study period has been chosen with the recognition that it cuts-across two political administrations. The relevance of this is that, it eliminates any special regulatory privileges or otherwise that may be associated with a particular political regime and which could thus influence the results.

Following Obamuyi (2013), the study uses descriptive statistics involving tables and bar graphs while employing time trend analysis, averages and percentage growth to investigate the financial intermediation function and profitability of the above selected banks in Ghana.

\section{Results and Discussions}

\subsection{Analyses of the Deposits of the Selected Banks}

Table 1 below shows the deposits of the selected eight banks from 2004-2010. It is observed that total deposits mobilized by the banks at the end of 2004 amounted to Gh $11,516,308,059.00$. However, by the end of 2010, this figure rose to Gh $\varnothing 7,322,893,388.00$ giving a large percentage increase of $382.9 \%$ whiles the combine average deposit of the banks stood at Ghø490,443,795.00 for the period under study. Table 1 further revealed that, comparatively, GCB mobilized the highest average deposits for the years under review, followed by BBGL, SCB, EBG, MBG, ADB, STANBIC, and finally NIB in that order. This tremendous performance of the banks in deposits mobilization firstly may be associated with higher deposits rate the country has seen during the study period relative to previous years. Secondly, it may also be attributed to increase customer education to save and also due to the relative stability of the cedi during the period under investigation. Furthermore, Table 2 and Figure 1 below revealed that deposit mobilization of all the individual banks had increased in absolute terms for the period under study. Nonetheless, performance of the banks in terms of their market share in deposit mobilization has rather been mixed.

For Ghana Commercial Bank Ltd. (GCB), total deposits mobilized at the end of 2004 stood at Gh $\varnothing 426,753,788.1$; representing $28.1 \%$ of total deposits of the selected banks for 2004 (see Table 2 and Figure 1 below). This amount increased to $\mathrm{Gh} \varnothing 1,575,281,050.00$ by the end of 2010 and constitutes $21.5 \%$ of total deposits of the selected banks for that year. This suggests that, there was an increase of $269.1 \%$ in GCB's deposit mobilization in absolute terms between 2004 and 2010 although its market share in total deposit mobilization fell by $6.6 \%$ for the same period under review.

Also, at the end of 2004, Standard Chartered Bank Ghana Ltd. (SCB) mobilized a total deposit of Ghø330,664,508.3; representing $21.8 \%$ of total deposits of the selected banks for 2004. This amount increased to 
Gh $\varnothing 1,092,638,000.00$ by the end of 2010 and constitutes $14.9 \%$ of total deposits of the selected banks for that year. This means that, there was an increase of $230.4 \%$ in SCB's deposit mobilization in absolute terms between 2004 and 2010 although its market share in total deposit mobilization fell by $6.9 \%$ for the same period under review.

Furthermore, at the end of 2004, Barclays Bank Ghana Ltd. (BBGL) mobilized a total deposit of Ghe280,265,201.7; representing $18.5 \%$ of total deposits of the selected banks for 2004. This amount increased to Gh $\varnothing 1,093,655,000.00$ by the end of 2010 and constitutes $14.9 \%$ of total deposits of the selected banks for that year. This implies that, there was an increase of $290.2 \%$ in BBGL's deposit mobilization in absolute terms between 2004 and 2010 although its market share in total deposit mobilization fell by $3.6 \%$ for the same period under review.

In addition to the above, at the end of 2004, Agricultural Development Bank (ADB) mobilized a total deposit of Ghe161,784,764.4; representing 10.7\% of total deposits of the selected banks for 2004. This amount increased to Gh $\varnothing 536,079,338.00$ by the end of 2010 and constitutes $7.3 \%$ of total deposits of the selected banks for that year. The implication is that, there was an increase of $231.4 \%$ in ADB's deposit mobilization in absolute terms between 2004 and 2010 although its market power in total deposit mobilization fell by $3.4 \%$ for the same period under review.

The fall in market power in total deposit mobilization of all the banks above (GCB, SCB, BBGL, and ADB) for the period under review may be attributed to the entry of foreign banks (Fidelity Bank, Guaranty Trust Bank, United Bank of Africa, UT Bank among others) into the Ghanaian banking industry which has since increased competition monopolistically in the sector (Biekpe, 2011). For example, it has been observed that the new banks have adopted more aggressive deposit mobilization strategies relative to most existing banks. Given that the Ghanaian bankable population is small and increasing at a decreasing rate relative to the emergence of new banks, the deposit clientele base of the existing banks is bound to dwindle.

For Ecobank Ghana Ltd. (EBG), deposits mobilized at the end of 2004 stood at Gh $\not 136,138,898.7$; representing 9\% of total deposits of the selected banks for 2004. This amount increased to Gh $\varnothing 1,086,935,000.00$ by the end of 2010 and constitutes $14.8 \%$ of total deposits of the selected banks for that year. This implies that, there was a remarkable increase of 698.4\% in EBG's deposit mobilization in absolute terms between 2004 and 2010 with its market share in total deposit mobilization increasing by $5.8 \%$ for the same period under review.

Deposits mobilized by Stanbic Bank Ghana Ltd. (STANBIC) at the end of 2004 stood at Gh $\varnothing 52,472,461.2$; representing $3.5 \% \%$ of total deposits of the selected banks for 2004. This amount increased to Gh $\varnothing 728,372,000.00$ by the end of 2010 and constitutes $9.9 \%$ of total deposits of the selected banks for that year. This gives an incredible increase of $1,288.1 \%$ in STANBIC's deposit mobilization in absolute terms between 2004 and 2010 with its market share in total deposit mobilization increasing by $6.4 \%$ for the same period under review.

For Merchant Bank Ghana (MBG), deposits mobilized at the end of 2004 was Gh $\varnothing 91,563,551.99$; representing 6\% of total deposits of the selected banks for 2004. This amount increased to Ghø711,130,000.00 by the end of 2010 and constitutes $9.7 \%$ of total deposits of the selected banks for that year. This gives a significant increase of $676.7 \%$ in MBG's deposit mobilization in absolute terms between 2004 and 2010 with its market share in total deposit mobilization increasing by $3.7 \% \%$ for the same period under review.

Lastly, National Investment Bank (NIB) had a deposit of Ghø36,664,884.3 at the end of 2004; representing 2.4\% of total deposits of the selected banks for 2004. This amount increased to Ghø498,803,000.00 by the end of 2010 and constitutes $6.8 \%$ of total deposits of the selected banks for that year. This gives a considerable increase of $1260.4 \%$ in NIB's deposit mobilization in absolute terms between 2004 and 2010 with its market share in total deposit mobilization increasing by $4.4 \%$ for the same period under review.

The increases in market power in total deposit mobilization of EBG, STANBIC, MBG, and NIB during the period under examination may be associated with a more intensive deposit mobilization policy being pursued by these banks relative to their four competitors discussed earlier.

Table 1. Deposits of the selected banks from 2004-2010 in Cedis (GHC)

\begin{tabular}{lcccccccc}
\hline BANK & $\mathbf{2 0 0 4}$ & $\mathbf{2 0 0 5}$ & $\mathbf{2 0 0 6}$ & $\mathbf{2 0 0 7}$ & $\mathbf{2 0 0 8}$ & $\mathbf{2 0 0 9}$ & $\mathbf{2 0 1 0}$ & Average \\
\hline GCB & 426753788 & 491473000 & 634572700 & 839382573 & 1030106198 & 1259470137 & 1575281050 & 893862778 \\
SCB & 330664508 & 328780000 & 466324000 & 578751000 & 752308000 & 844519000 & 1092638000 & 627712073 \\
BBGL & 280265202 & 334877000 & 489738000 & 720040000 & 923858000 & 933888000 & 1093655000 & 682331600 \\
EBG & 136138899 & 178178000 & 335637000 & 437950000 & 682705000 & 862810000 & 1086935000 & 531479128 \\
ADB & 161784764 & 162159000 & 234414300 & 271024641 & 319499930 & 425144815 & 536079338 & 301443827 \\
\hline
\end{tabular}




\begin{tabular}{lllllllll}
\hline STANBIC & 52472461 & 69312000 & 1160793 & 266201000 & 369905000 & 590976000 & 728372000 & 296914179 \\
MBG & 91563552 & 69312000 & 275830000 & 401498000 & 366024000 & 611686000 & 711130000 & 361006222 \\
NIB & 36664884 & 60798000 & 169754000 & 244583000 & 254283000 & 336718000 & 498803000 & 228800555 \\
Total & 1516308059 & 1694889000 & 2607430793 & 3759430214 & 4698689128 & 5865211952 & 7322893388 & 3923550362 \\
AVERAGE & & & & & & & & 490443795 \\
\hline
\end{tabular}

Source: Authors' Compilation from the Annual Reports of the Selected Banks (2004-2010).

Note. Percentage increase in deposits of the selected banks from 2004-2010 $=382.9 \%$

Table 2. Comparative analysis of deposits of the selected banks in Gh $\not$ (2004-2010)

\begin{tabular}{lllll}
\hline BANK & $\mathbf{2 0 0 4}$ & \% of Total & $\mathbf{2 0 1 0}$ & \% of Total \\
\hline GCB & 426753788.1 & 28.14426697 & 1575281050 & 21.51172995 \\
SCB & 330664508.3 & 21.80721169 & 1092638000 & 14.92085085 \\
BBGL & 280265201.7 & 18.48339459 & 1093655000 & 14.9347388 \\
EBG & 136138898.7 & 8.978313999 & 1086935000 & 14.84297179 \\
ADB & 161784764.4 & 10.66965011 & 536079338 & 7.320594601 \\
STANBIC & 52472461.2 & 3.460540943 & 728372000 & 9.946505587 \\
MBG & 91563551.99 & 6.038585066 & 711130000 & 9.711052207 \\
NIB & 36664884.3 & 2.418036631 & 498803000 & 6.811556219 \\
Total & 1516308059 & & 7322893388 & \\
\hline
\end{tabular}

Source: Authors' Compilation from the Annual Reports of the Selected Banks (2004-2010).

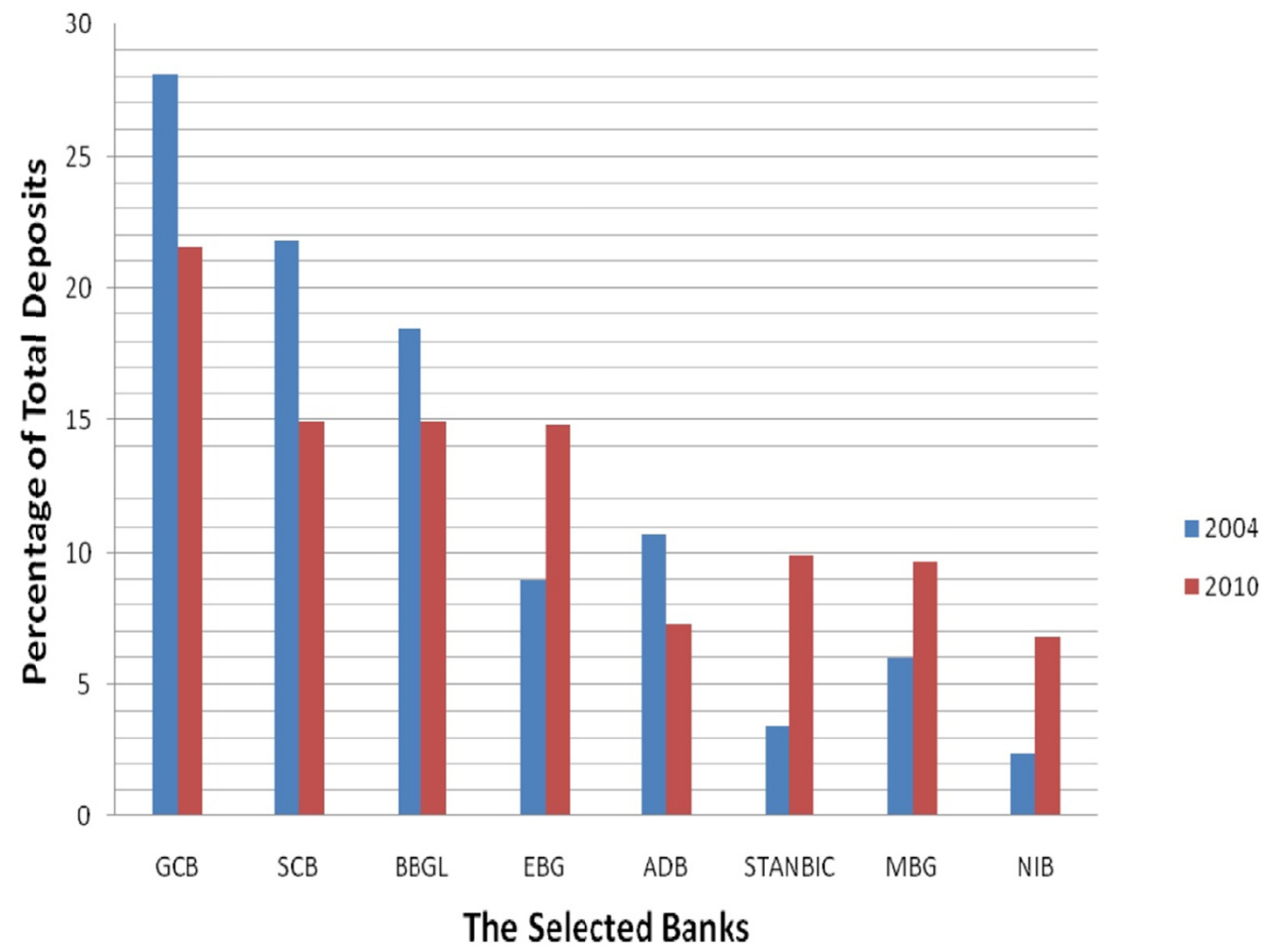

Figure 1. Deposit behaviour of the selected banks (2004 and 2010)

\subsection{Analyses of the Loans and Advances of the Selected Banks}

Table 3 below shows the loans and advances of the selected eight banks from 2004-2010. It is observed that total loans and advances mobilized by the banks at the end of 2004 amounted to Gh $\varnothing 813,092,345.1$. Nonetheless, by the end of 2010, this figure rose to Gh $\varnothing 4,297,525,326.00$ indicating a percentage increase of $428.5 \%$ whiles the combined average loans and advances of the banks stood at Ghф322,241,490.9 for the period under investigation. Table 3 further shows that, relatively, GCB made the highest average loans and advances for the study period, 
followed by BBGL, EBG, MBG, ADB, SCB, STANBIC, and finally NIB in that order. This significant improvement in granting out loans and advances within the study period may be attributed to increase competition in the Ghanaian banking sector for increase customer base. It may also be associated with the expansion in the Ghanaian economy which has since propelled demand for loans and advances. One key observation from the study is that, generally, apart from SCB, banks which mobilized relatively higher average deposits appears to have granted most loans and advances on average. Additionally, Table 4 and Figure 2 below show that loans and advances of all the individual banks had improved in absolute terms for the period under examination. Nonetheless, performance of the banks in terms of market share in granting out loans and advances has rather been mixed.

In the case of GCB, total loans and advances at the end of 2004 stood at Gh $\varnothing 202,373,587.1$; indicating $24.9 \%$ of total loans and advances of the selected banks for 2004 (see Table 4 and Figure 2 below). This amount increased to Gh $11,003,682,422.00$ by the end of 2010 and constitutes $23.4 \%$ of total loans and advances of the banks for that year. This gives an increase of 396\% in GBC's granting of loans and advances in absolute terms between 2004 and 2010 though its market share in the same activity fell by $1.5 \%$ for the same period under review.

For SCB, loans and advances was Ghø163,674,389.9 at the end of 2004; indicating 20.1\% of total loans and advances of the selected banks for 2004. This amount increased to Ghø568,182,000.00 by the end of 2010 and constitutes $13.2 \%$ of total loans and advances of the banks for that year. This gives an increase of $247.1 \%$ in SCB's granting of loans and advances in absolute terms between 2004 and 2010 though its market share in the same activity fell by $6.9 \%$ for the same period under investigation.

For BBGL, loans and advances was Gh $\varnothing 206,505,649.00$ at the end of 2004; indicating $25.4 \%$ of total loans and advances of the selected banks for 2004. This amount increased to Gh $\varnothing 435,918,000.00$ by the end of 2010 and constitutes $10.1 \%$ of total loans and advances of the banks for that year. This gives an increase of $111.1 \%$ in BBGL's granting of loans and advances in absolute terms between 2004 and 2010 though its market share in the same activity fell by $15.3 \%$ for the same period under examination.

In the same vein, NIB's loans and advances was Ghø77,711,935.6 at the end of 2004; indicating $9.6 \%$ of total loans and advances of the selected banks for 2004. This amount increased to Ghø326,977,000 by the end of 2010 and constitutes $7.6 \% \%$ of total loans and advances of the banks for that year. This gives an increase of $320.76 \%$ in NIB's granting of loans and advances in absolute terms between 2004 and 2010 though its market share in the same activity fell by $2 \%$ for the same period under evaluation.

Despite the fact that GCB, SCB, BBGL, and NIB have all performed creditably well in absolute terms in granting loans and advances over the study period, the fall in their market power in the same activity over the same period may be attributed to increase competition in the Ghanaian banking sector as indicated above and also possibly the relatively higher lending rates charged by these banks which may deter many customers from borrowing from these institutions. Distinctively, the enormous fall in BBGL's market power in granting loans and advances for the study period (though the second highest in granting loans and advances in absolute terms) may also be associated with the bank's conservative lending policies. The fact is that, on average, doubtful debt accounts in the Ghanaian banking sector has exacerbated since the advent of foreign banks into the Ghanaian banking scene (Ghana Banking Survey, 2009).

In the case of EBG, loans and advances was Gh $\varnothing 69,548,073.81$ at the end of 2004; indicating $8.6 \%$ of total loans and advances of the selected banks for 2004. This amount increased to Gh $\varnothing 495,691,000.00$ by the end of 2010 and constitutes $11.5 \%$ of total loans and advances of the banks for that year. This gives an increase of $612.7 \%$ in EBG's granting of loans and advances in absolute terms between 2004 and 2010 with an increased market power in the same activity by $2.9 \%$ for the same period under assessment.

Total loans and advances of ADB stood at Ghø8,349,285.5 at the end of 2004; indicating 1.0\% of loans and advances of the selected banks for 2004. This amount increased to Ghø576,986,904.00 by the end of 2010 and constitutes $13.4 \%$ of total loans and advances of the banks for that year. This gives a remarkable increase of $6810.6 \%$ in ADB's granting of loans and advances in absolute terms between 2004 and 2010 with an increased market power in the same activity by $12.4 \%$ for the same period under assessment.

For STANBIC, total loans and advances was Gh $\varnothing 19,955,290.8$ at the end of 2004; indicating $2.5 \%$ of loans and advances of the selected banks for 2004. This amount increased to Ghø441,734,000.00 by the end of 2010 and constitutes $10.3 \%$ of total loans and advances of the banks for that year. This gives a significant increase of $2113.6 \%$ in STANBIC's granting of loans and advances in absolute terms between 2004 and 2010 with an increased market power in the same activity by $7.8 \%$ for the same period under appraisal.

Last but not the least, MBG recorded Ghø64,974,133.4 in total loans and advances at the end of 2004; indicating 8\% 
of loans and advances of the selected banks for 2004. This amount increased to Ghø448,354,000.00 by the end of 2010 and constitutes $10.4 \%$ of total loans and advances of the banks for that year. This gives an increase of $590.0 \%$ in MBG's granting of loans and advances in absolute terms between 2004 and 2010 with an increased market power in the same activity by $2.4 \%$ for the same study period.

The absolute increases in loans and advances couple with increases in market power of EBG, ADB, STANBIC, and MBG for the study period may be attributed to their aggressive lending strategies and comparatively lower lending rates. In Ghana, it is not uncommon to see casual employees of these banks moving from office to office and selling their bank's loan products to potential customers. Specifically, ADB has out-performed all the other seven selected banks in granting loans and advances in both absolute terms and average market power $(6810.6 \%$ and by $12.4 \%$ respectively) for the period under investigation. This may be attributed to successive government's Special Directive to the bank to extend more credit facility to the agricultural sector (mainly cocoa production, fishing, and animal husbandry) to boost production and generate employment in the country.

Table 3. Loans and advances of the selected banks from 2004-2010 in Cedis (GHф)

\begin{tabular}{llccrrrrc}
\hline BANK & $\mathbf{2 0 0 4}$ & $\mathbf{2 0 0 5}$ & $\mathbf{2 0 0 6}$ & $\mathbf{2 0 0 7}$ & $\mathbf{2 0 0 8}$ & $\mathbf{2 0 0 9}$ & $\mathbf{2 0 1 0}$ & Average \\
\hline GCB & 202373587.1 & 322166000 & 364538500 & 742696325 & 1087118928 & 1265516727 & 1003682422 & 712584641.3 \\
SCB & 163674389.9 & 172680000 & 87402000 & 93861000 & 153776000 & 480613000 & 568182000 & 245741198.6 \\
BBGL & 206505649 & 268335000 & 362980000 & 640558000 & 718598000 & 513717000 & 435918000 & 449515949.9 \\
EBG & 69548073.81 & 103124000 & 162245000 & 285772000 & 401531000 & 448463000 & 495691000 & 280910582 \\
ADB & 8349285.5 & 109115000 & 150923300 & 150923300 & 370606658 & 372864956 & 576986904 & 248538486.2 \\
STANBIC & 19955290.8 & 266884000 & 722125 & 241277000 & 287717000 & 345635000 & 441734000 & 194817773.7 \\
MBG & 64974133.4 & 98756000 & 218482000 & 294260000 & 308407000 & 336546000 & 448354000 & 252825590.5 \\
NIB & 77711935.6 & 88906000 & 137736000 & 194933000 & 240232000 & 284488000 & 326977000 & 192997705.1 \\
Total & 813092345.1 & 1189766000 & 1485028925 & 2644280625 & 3567986586 & 4047843683 & 4297525326 & 2577931927 \\
AVERAGE & & & & & & & & \\
\hline
\end{tabular}

Source: Authors' Compilation from the Annual Reports of the Selected Banks (2004-2010).

Note. Percentage increase in loans and advances of the selected banks from 2004-2010=428.5\%.

Table 4. Comparative analysis of loans and advances of the selected banks in Gh $\not$ (2004-2010)

\begin{tabular}{lllll}
\hline BANKS & \multicolumn{2004}{c}{} & \% of Total 2004 & 2010 & \% of Total 2010 \\
\hline GCB & 202373587.1 & 24.88937306 & 1003682422 & 23.35489255 \\
SCB & 163674389.9 & 20.12986482 & 568182000 & 13.22114373 \\
BBGL & 206505649 & 25.39756403 & 435918000 & 10.14346553 \\
EBG & 69548073.81 & 8.553527066 & 495691000 & 11.53433575 \\
ADB & 8349285.5 & 1.02685575 & 576986904 & 13.42602685 \\
STANBIC & 19955290.8 & 2.454246547 & 441734000 & 10.27879923 \\
MBG & 64974133.4 & 7.990990666 & 448354000 & 10.43284137 \\
NIB & 77711935.6 & 9.557578062 & 326977000 & 7.60849501 \\
Total & 813092345.1 & & 4297525326 & \\
\hline
\end{tabular}

Source: Authors' Compilation from the Annual Reports of the Selected Banks (2004 - 2010). 


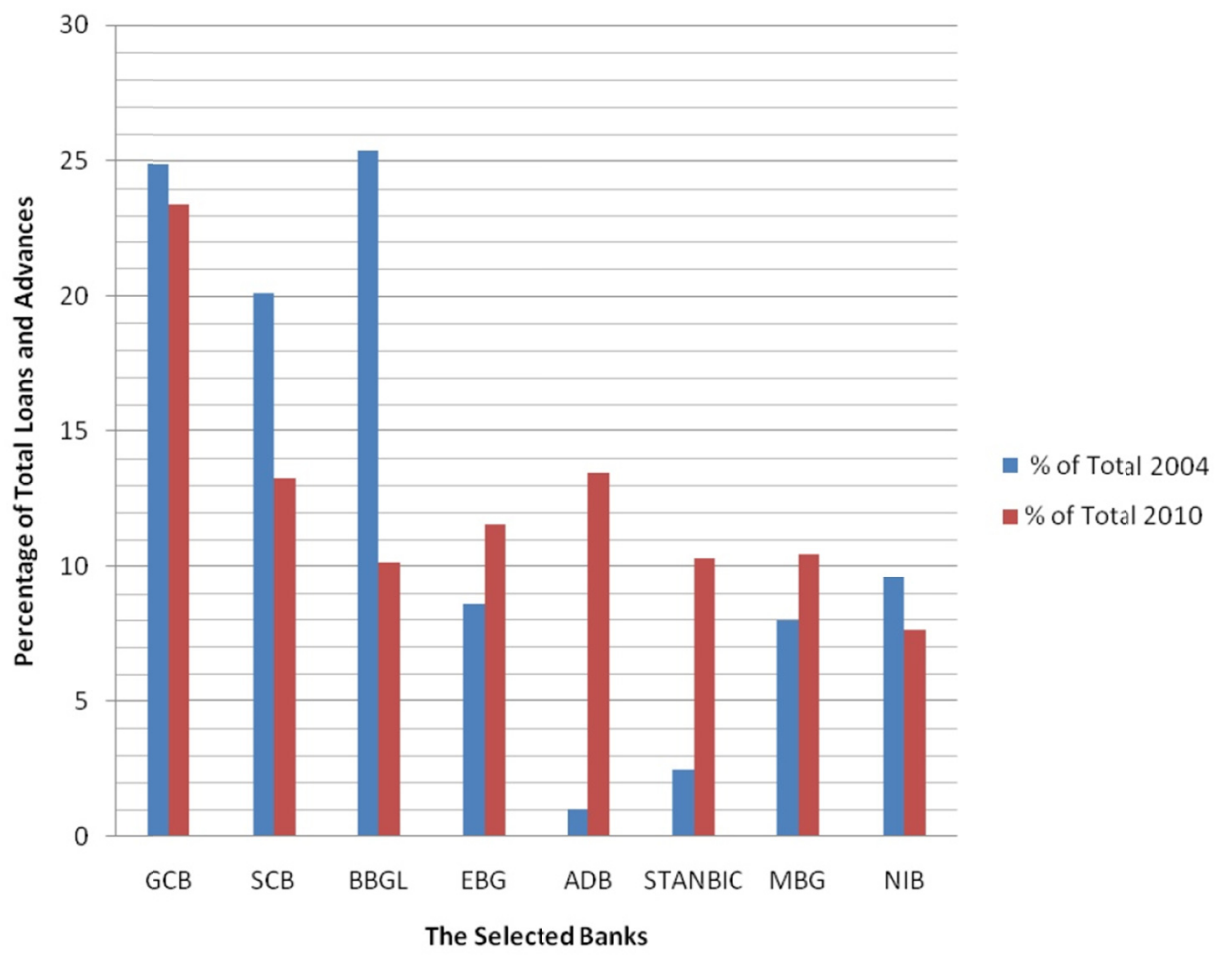

Figure 2. Behaviour of loans and advances of the selected banks (2004 and 2010)

\subsection{Analyses of Profits of the Selected Banks}

Table 5 below indicates the profit behavior of the selected eight banks from 2004-2010. It is observed that total profits mobilized by the banks at the end of 2004 amounted to Gh\&82,300,388.9. However, by the end of 2010, this figure rose to Gh $\varnothing 304,755,333.00$ indicating a percentage increase of $270.3 \%$ whiles the combined average profit of the banks stood at Ghø18,864,780.00 for the period under examination. Table 5 further shows that, relatively, SCB made the highest average profits for the study period, followed by EBG, GCB, BBGL, STANBIC, $\mathrm{ADB}, \mathrm{MBG}$, and finally NIB in that order. This improvement in the profit performance of the banks within the study period may be attributed generally to relatively higher lending rates compared to previous years, the significant increase in deposits mobilized within the period under study (382.9\%), and also relatively increase business activity within the Ghanaian economy for the period under investigation due to stability in inflation.

An important observation in the profit performance of the banks lies in the fact that, generally, banks which recorded the highest profits were not necessarily the ones which made out most loans and advances and vice versa. For example, Table 3 shows that GCB and BBGL were the first and second respectively to have granted out most loans and advances on average within the study period but placed third and fourth respectively in average profit performance according to Table 5. Another example is that, SCB which was the sixth highest out of the eight banks in granting out loans and advances on average turns out to be the most profitable bank for the period under examination. A plausible reason may be due to prudent cost management strategies being adopted by SCB. A significant observation in Ghanaian banking is that, almost all the banks do "high street" banking and operate from luxurious premises couple with comparatively high salaries they pay to their employees in the name of poaching them from their previous employers. These activities obviously will have implication for increased cost of doing business with its attendant problems and thus must be checked. Furthermore, Table 6 and Figure 3 below show that besides NIB, the profit performance of all the individual banks had improved in absolute terms for the period under examination. Nevertheless, the performance of the banks in terms of their relative profit has rather been mixed.

For GCB, total profits at the end of 2004 stood at Ghø17,793,450.1; representing $21.6 \%$ of total profits of the selected banks for 2004 (see Table 6 and Figure 3 below). This amount increased to Gh $\varnothing 55,432,230.00$ by the end of 2010 and constitutes $18.2 \%$ of total profits of the selected banks for that year. This implies that, there was an increase of $211.5 \%$ in GCB's profit in absolute terms between 2004 and 2010 although its share of relative profit fell by $3.4 \%$ for the same period under review.

For BBGL, total profits at the end of 2004 stood at Ghø27,791,618.3; representing 33.8\% of total profits of the 
selected banks for 2004 . This amount increased to Gh $\varnothing 59,244,000.00$ by the end of 2010 and constitutes $19.4 \%$ of total profits of the selected banks for that year. The implication is that, there was an increase of $113.2 \%$ in BBGL's profit in absolute terms between 2004 and 2010 although its share of relative profit fell by $14.4 \%$ for the same period under evaluation.

Similarly, MBG total profits at the end of 2004 stood at Gh $₫ 3,356,411.00$; representing $4.1 \%$ of total profits of the selected banks for 2004. This amount increased to Ghø4,629,000.00 by the end of 2010 and constitutes $1.5 \%$ of total profits of the selected banks for that year. The implication is that, there was an increase of $37.9 \%$ in MBG's profit in absolute terms between 2004 and 2010 although its share of relative profit fell by $2.6 \%$ for the same period under evaluation.

In the same way, NIB's total profits at the end of 2004 stood at Ghø6,810,666.4; representing $8.3 \%$ of total profits of the selected banks for 2004. This figure fell to Gh $\varnothing 2,424,000.00$ by the end of 2010 and constitutes $0.8 \%$ of total profits of the selected banks for that year. This led to a decrease of $64.4 \%$ in NIB's profit in absolute terms between 2004 and 2010 couple with the fact that its share of relative profit also fell by $7.5 \%$ for the same period under assessment.

The fall in relative profit share of GCB, BBGL, MBG, and NIB between 2004-2010 may be associated with increase competition in the Ghanaian banking industry (Biekpe, 2011 and Ghana Banking Survey, 2009) which has since been narrowing the margins, couple with the increasing cost of doing the business of banking in Ghana (high employee salaries and operating from luxurious premises as indicated earlier, and increasing utility bills). Specifically, the decline in the profit performance of NIB and the abysmal profit performance of MBG over the study period is not surprising as it is evident that these banks, being state-owned constantly suffer from the "interference" of politicians.

For SCB, total profits at the end of 2004 stood at Gh $\varnothing 16,847,444.3$; representing $20.5 \%$ of total profits of the selected banks for 2004. This amount increased to Gh $\varnothing 72,208,000.00$ by the end of 2010 and constitutes $23.7 \%$ of total profits of the selected banks for that year. This suggests that, there was an increase of $328.6 \%$ in SCB's profit in absolute terms between 2004 and 2010 with an increase in its share of relative profit going up by $3.2 \%$ for the same period under examination.

Also, EBG had a total profit of Ghø8,050,971.81 at the end of 2004; representing $9.8 \%$ of total profits of the selected banks for 2004. This amount increased to Gh $\varnothing 58,604,000.00$ by the end of 2010 and constitutes $19.2 \%$ of total profits of the selected banks for that year. This means that, there was an increase of $627.9 \%$ in EBG's profit in absolute terms between 2004 and 2010 with an increase in its share of relative profit going up by $9.4 \%$ for the same period under review.

Likewise, ADB had a total profit of Gh $125,109.48$ at the end of 2004; representing $0.15 \%$ of total profits of the selected banks for 2004. This amount increased to Ghø33,215,103.00 by the end of 2010 and constitutes $10.9 \%$ of total profits of the selected banks for that year. This means that, there was a tremendous increase of $26,448.8 \%$ in ADB's profit in absolute terms between 2004 and 2010 with an increase in its share of relative profit going up by $10.75 \%$ for the same period under study.

Finally, STANBIC bank had a total profit amounting to Gh $\varnothing 1,524,717.5$ at the end of 2004; representing $1.9 \%$ of total profits of the selected banks for 2004. This amount increased to Gh $\varnothing 18,999,000.00$ by the end of 2010 and constitutes $6.2 \%$ of total profits of the selected banks for the period under review. This means that, there was a remarkable increase of 1,146.1\% in STANBIC's profit in absolute terms between 2004 and 2010 with an increase in its share of relative profit going up by $4.3 \%$ for the same period under assessment.

The increases in both the absolute amounts and the relative market share in the profit performance of SCB, EBG, ADB, and STANBIC may be attributed to prudent management with aggressive cost cutting strategy as its centerpiece. It may also be associated with their relatively lower lending rates compared to the other banks. 
Table 5. Profit behaviour of the selected banks from 2004-2010 in Cedis (GHC)

\begin{tabular}{lllllllll}
\hline BANK & $\mathbf{2 0 0 4}$ & $\mathbf{2 0 0 5}$ & $\mathbf{2 0 0 6}$ & $\mathbf{2 0 0 7}$ & $\mathbf{2 0 0 8}$ & $\mathbf{2 0 0 9}$ & $\mathbf{2 0 1 0}$ & Average \\
\hline GCB & 17793450.1 & 12900000 & 25540600 & 24849522 & 37004851 & 18117151 & 55432230 & 27376829 \\
SCB & 16847444.3 & 23200000 & 30748000 & 33038000 & 33187000 & 57497000 & 72208000 & 38103635 \\
BBGL & 27791618.3 & 26900000 & 36303000 & 31530000 & -7350000 & -20291000 & 59244000 & 22018231 \\
EBG & 8050971.81 & 12600000 & 16238000 & 19829000 & 33579000 & 53853000 & 58604000 & 28964853 \\
ADB & 125109.482 & 7500000 & 10765000 & 9278832 & 14934890 & 12667366 & 33215103 & 12640900 \\
STANBIC & 1524717.5 & 1600000 & 24861281 & 52189490 & 14717000 & 1042000 & 18999000 & 16419070 \\
MBG & 3356411 & 6400000 & 9274000 & 10740000 & 23046000 & 5667000 & 4629000 & 9016058.7 \\
NIB & 6810666.4 & 5900000 & 4427000 & 5989000 & -28574000 & -22326000 & 2424000 & 3621333.4 \\
Total & 82300388.9 & 97000000 & $1.58 \mathrm{E}+08$ & 187443844 & 120544741 & 106226517 & 304755333 & 150918244 \\
AVERAGE & & & & & & & & 18864780 \\
\hline
\end{tabular}

Source: Authors' Compilation from the Annual Reports of the Selected Banks (2004-2010).

Note. Percentage increase in profits of the selected banks from $2004-2010=270.3 \%$.

Table 6. Comparative Analysis of Profit Behaviour of the Selected Banks in Gh $\varnothing$ (2004-2010)

\begin{tabular}{lllll}
\hline BANK & \multicolumn{1}{c}{$\mathbf{2 0 0 4}$} & \% of Total 2004 & \multicolumn{1}{c}{ 2010 } & \% of Total 2010 \\
\hline GCB & 17793450.1 & 21.62012882 & 55432230 & 18.18909269 \\
SCB & 16847444.3 & 20.47067399 & 72208000 & 23.69376092 \\
BBGL & 27791618.3 & 33.76851395 & 59244000 & 19.43985669 \\
EBG & 8050971.81 & 9.78242256 & 58604000 & 19.22985216 \\
ADB & 125109.482 & 0.152015663 & 33215103 & 10.89894069 \\
STANBIC & 1524717.5 & 1.852624903 & 18999000 & 6.234181306 \\
MBG & 3356411 & 4.078244399 & 4629000 & 1.518923378 \\
NIB & 6810666.4 & 8.27537572 & 2424000 & 0.795392152 \\
Total & 82300388.89 & & 304755333 & \\
AVERAGE & & & & \\
\hline
\end{tabular}

Source: Authors' Compilation from the Annual Reports of the Selected Banks (2004-2010).

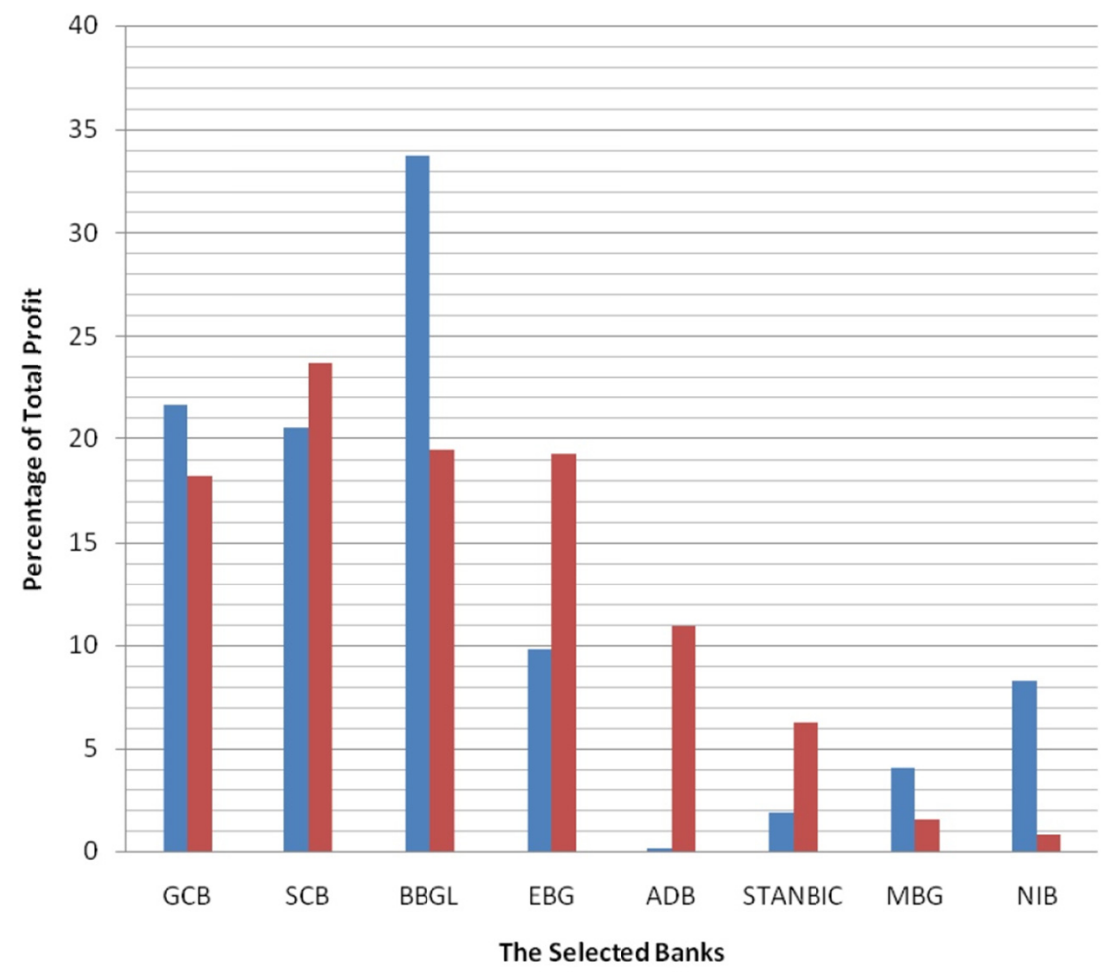

Figure 3. Profit behaviour of the selected banks (2004-2010) 


\section{Conclusions and Recommendations}

Shaw (1973) in his seminal work argues that the extent to which banks perform their primary financial intermediation function has consequences for the economic development of their countries. Whereas empirical evidence shows that the relationship between financial intermediation and profitability of banks have focused on advanced countries with mixed findings, the relationship remains largely under studied in the developing world. Using descriptive evaluation technique, this study investigated the extent of financial intermediation and its implication for profitability in Ghanaian banking.

Generally, we observe that in the Ghanaian banking industry, the financial intermediation function has been performed creditably well over the study period given the large increases in both absolute and relative market share in deposit mobilization, granting of loans and advances, and profitability. Specifically, we noticed that on average banks which mobilized most deposits were also the ones that recorded most loans and advances and vice versa. This suggests that a bank's ability to mobilize deposits has implications for the quantum of loans and advances it can give (Jayaratne \& Morgan, 1997; Obamuyi, 2013). We further discover that banks that made the most loans and advances were not necessarily those that made most profits. The implication is that besides making out loans and advances to customers, prudent cost management is also very crucial in banking in order to remain profitable. Additionally, we also report that, on average state-owned banks appears to be less efficient (except ADB) in their financial intermediation function and thus less profitable relative to the other banks.

To remain profitable in the banking business in Ghana, management must not only put strategies in place to mobilize deposits and make out loans, but also put measures in place to efficiently manage cost. Government, through the central bank monetary policy committee must put policies in place that will enable banks to mobilize more deposits. For example increasing the deposit rate and also encouraging the banks to employ new strategies to consciously mobilize deposits. Finally, Government should also avoid unnecessary interference in the management of state-owned banks so as to make them more efficient and profitable.

\section{References}

Amidu, M. (2006). The link between monetary policy and banks lending behaviour: The Ghanaian case. Banks and Bank Systems, 1(4), 44-46.

Azmi, S. H. (2006). Measuring depositors' behaviour of Malaysian Islamic banking system: A Co-integration Approach (pp. 21-24). In 6th International Conference on Islamic Economics and Finance, Bank Indonesia, Jakarta, Indonesia. Jakarta, Indonesia.

Biekpe, N. (2011). Competitiveness of commercial banks in Ghana. African Development Review, 23(1), $75-87$.

Blinder, B. B. (1992). The federal funds and the transmission of monetary policy. American Economic Review, $82,901$.

Carletti, E. (2004). The structure of bank relationships, endogenous monitoring and loan rates. Journal of Financial Intermediation, 58-86.

Edward, S. (1973). Financial deepening in economic development. Business and Economics Review. New York: Oxford University Press.

Ghana Banking Survey. (2009).

Ghana Banking Survey. (2012).

H., M. C. (2005). Bank Lending and Monetary Policy: Evidence on a Credit Channel. Economic Review, 59-75.

Jayaratne, J., \& Morgan, D. (1997). Information problems and deposit constraints at banks. Retrieved from http://www.newyorkfed.org/research/staff_reports/research_papers/9731.pdf

Kiezenkowski, R. (2001). The bank lending channel and the efficiency of monetary policy during transition: The case of Poland. The Center for Economic Policy Research Working Paper.

McKinnon, I. R. (1973). Money and capital in economic development (pp. 8-9). Brooking Institution Press.

Mensah, S. (2005). Challenges and Opportunities facing the Financial Services Industry in a Stable Macroeconomic Environment. Accra, Ghana: Chartered Institute of Bankers.

Micheal, C. B., Ezirim, C. B., \& Muoghalu, M. I. (2006). Financial management imperatives of intermediation function of financial institutions: Empirical evidence from Nigeria. Banks and Bank System, 1(3), 116.

Mishkin, F. S. (2012). The economics of money and banking. Global Ed of 10th Revised. London: Pearson Education. 
Obamuyi, T. M. (2013). An analysis of the deposits and lending behaviours of banks in Nigeria. International Journal of Engineering and Management Sciences, 46-54.

Olokoyo, F. O. (2011). Determinatants of commercial banks lending behaviour in Nigeria. International Journal of Financial Research, 2, 61-72.

Onyekachi, V. O. (2013). Effect of bank lending rate on the performance of Nigerian deposit money banks. International Journal of Business and Mangement Review, 34-43.

Shaw, E. (1973). Financial deepening in economic development. New York, NY: Oxford University Press.

Suwanaporn, C. (2004). Determinants of bank lending in Thailand: An empirical examination for the years 1992-1996. Unpublished Thesis.

\section{Copyrights}

Copyright for this article is retained by the author(s), with first publication rights granted to the journal.

This is an open-access article distributed under the terms and conditions of the Creative Commons Attribution license (http://creativecommons.org/licenses/by/3.0/). 